\title{
Martin County, Florida Food System Study ${ }^{1}$
}

\author{
William A. Messina, Jr., Lisa House, Yvette Goodiel, and Carol Alberts²
}

\section{Background}

Martin County has a rich agricultural history with farming (particularly citrus) and cattle ranching being important economic drivers since the early 1930s (Martin County Business Development Board). Even today, almost 50 percent of the county's land area remains in agricultural production (Martin County Property Appraiser 2019).

According to the most recent (2017) federal Census of Agriculture, Martin County has 594 farms, with 153,732 acres of agricultural land (USDA-NASS 2019). A study by the UF/IFAS Food and Resource Economics Department calculates that in 2016, agriculture, natural resources, and related food industries accounted for 24.2 percent of employment in Martin County, and $\$ 1.2$ billion worth of Value Added Contribution, ${ }^{1}$ which represents over 18 percent of the county's total Value Added Contribution (Court, Hodges, and Rahmani 2018).

Food crops produced in Martin County include vegetables, melons, fruits, sugarcane, fish, poultry/eggs, and beef. The principal vegetable and melon crops grown in Martin County include cabbages, potatoes, tomatoes, and watermelons (FDACS 2016). Top commercial fishing landings are of Spanish and King mackerel (Butch Olsen, Port Salerno Commercial Fishing Dock Authority, personal communication). Court, Hodges, and Rahmani (2018) estimate value added contributions of $\$ 8 \mathrm{M}$ for vegetable and melon farming, $\$ 61 \mathrm{M}$ for fruit farming, $\$ 23 \mathrm{M}$ for commercial fishing, $\$ 6 \mathrm{M}$ for poultry and egg production, and $\$ 7 \mathrm{M}$ for beef cattle ranching and farming.

While agricultural production occurs on almost half of the county's land and accounts for almost 20 percent of the county's total value added contribution, the Martin County region struggles to meet the balance between food supply and demand. Farmers often struggle to find sizable, secure, well-paying markets, and the vast majority of consumers do not participate in local food transactions. It therefore was anticipated that the food supply chain in the region might benefit from a "food hub," defined by the USDA as a "centrally located facility with a business management structure that facilitates the aggregation, storage, processing, distribution, and/or marketing of locally/regionally produced food products" (USDA-AMS 2010: 1).

The Martin County Food System Feasibility Study, funded by a USDA Rural Business Development Grant, identified regional food system constraints and opportunities, including opportunities for a food hub and/or farm incubator to strengthen the food supply chain and opportunities for expanding connectivity among supply chain participants to improve food security and increase access to local foods. While focus was on a county and its surrounding areas, the

1. This document is FE1071, one of a series of the Food and Resource Economics Department, UF/IFAS Extension. Original publication date December 2019. Visit the EDIS website at https://edis.ifas.ufl.edu for the currently supported version of this publication.

2. William A. Messina, Jr., research and development coordinator, Food and Resource Economics Department; Lisa House, professor and chair, Food and Resource Economics Department; Yvette Goodiel, sustainability \& commercial horticulture agent III, UF/IFAS Extension Martin County; and Carol Alberts, community resource development agent I, UF/IFAS Extension St. Lucie County; UF/IFAS Extension, Gainesville, FL 32611.

This publication is a summary of two longer reports: Martin County Food System Feasibility Study and Martin County Food System Infrastructure Analysis.

The Institute of Food and Agricultural Sciences (IFAS) is an Equal Opportunity Institution authorized to provide research, educational information and other services only to individuals and institutions that function with non-discrimination with respect to race, creed, color, religion, age, disability, sex, sexual orientation, marital status, national origin, political opinions or affiliations. For more information on obtaining other UF/IFAS Extension publications, contact your county's UF/IFAS Extension office. U.S. Department of Agriculture, UF/IFAS Extension Service, University of Florida, IFAS, Florida A \& M University Cooperative Extension Program, and Boards of County Commissioners Cooperating. Nick T. Place, dean for UF/IFAS Extension. 
Martin County study methodology can serve as a template for similar studies in other regions, and the study results can contribute toward a better understanding of food system constraints and opportunities on a broader level.

\section{Methods}

The study incorporated over a dozen interviews of supply side participants in the Martin County food system (e.g., growers and producers), and hundreds of demand side interviews (e.g., with consumers, restaurants, food distributors, the local school system, etc.), to assess current food system needs, as well as to analyze existing infrastructure and its potential to address constraints and support opportunities for food system improvement. Local stakeholders serving on the Martin County Agriculture and Natural Resources Advisory Committee helped to guide efforts during the study, developing a list of potential interviewees and reviewing draft survey tools. Additionally, representatives from the Martin County Business Development Board, Treasure Coast Regional Planning Council, Martin County Economic Development Council, and the Martin County Growth Management Department provided input on the draft reports, particularly in terms of potential food system resources, constraints, and opportunities.

Supply side interviews were conducted with local growers to better understand their current operations and local consumer marketing efforts and to gauge their interest in potential food system enhancements, such as a food hub, expanded local food supply for low-income residents, and/ or a farm incubator program.

Demand side interviewees included wholesale distributors, large institutional buyers, retail produce markets, restaurants, and approximately 350 Martin County residents. Interviewees provided information on their purchases of fruit/vegetable/protein sources, including pricing, purchase criteria, desire for "local" foods, types of fresh fruits/ vegetables/proteins purchased, purchase locations, transportation, and constraints to purchasing fresh produce and proteins. Additional input was provided by consumers and agribusinesses through public meetings and online surveys.

The analysis of existing food system infrastructure was conducted through interviews with operators of existing infrastructure facilities. Interviewees were asked to identify the capabilities of their operation (processing, packing, commercial kitchen, storage, etc.), discuss sourcing and transport of products, share information on the types of buyers served, note primary months of operation, and indicate whether there would be capacity for additional products. Lastly, interviewees were asked to share their perspective on the primary needs of the local food system.

\section{Recommendations}

Through the interviews and surveys, it became clear that the region has a strong, though somewhat fragmented, network of growers, distributors, food pantries/banks, small-scale food hubs, processing facilities, markets, and commercial kitchens. Demand side operations expressed a need for additional supply, and over 90 percent of consumer respondents indicated that they think "buying local" is very or at least somewhat important. Therefore, an opportunity exists in Martin County to make the most of the existing food chain structures and non-profit participants and build upon them to potentially cultivate new producers and market channels to better meet local demand. Study results and recommendations have been shared with local decision-makers and other stakeholders to inform future policies and programs.

In determining how to make the best use of existing infrastructure, several key components are recommended, including better connecting participants along the food chain to maximize efficiencies; examining approaches other communities have taken to improve their local food systems; engaging agribusiness and food entrepreneurs in productive discussions with local policy-makers to clarify and revise regulations where needed; training food chain staff and volunteers in food production, food safety, and other needed skill sets; and offering branding options to help producers better market their produce to local consumers. The experience and knowledge of growers who supply local markets, as well as those who supply a wider distribution network, can inform efforts to maximize use of existing local food infrastructure. For example, when asked about the feasibility of supplying a food hub outlet in the region, growers shared that pricing and transportation would first need to be addressed. Additionally, the risk of shifting from established relationships with buyers and distributors to a new hub might preclude growers from participating, unless they could begin engaging through provision of excess product. By more closely connecting growers with one another and with demand side buyers, all could learn more of each other's capabilities, share food processing resources, improve outreach to and accessibility for consumers, and communicate needs or excess supply year-round.

As food chain participants engage with one another locally, they can also learn from food system innovations in other communities, including mobile food pantries and food 
hubs; hearing from communities about not only their successes but also their failures can provide valuable insights. Where local food system developments are stymied by concerns over regulations, dialogue with policy-makers and regulators can help to clarify regulations, thereby reducing risk and uncertainty. Where needed, dialogue can lead to policy change, particularly where regulations may not be adapted to, or comprehensive of, new food system innovations.

Risk and uncertainty can also be addressed through training of food system staff and volunteers; interviewees identified training needs in areas such as food safety, food production, methods or systems to allow extension of the production season, alternative crops, hospitality, and worker safety.

Marketing and branding were areas where some felt that additional education and resources would be of benefit. As a first step, connecting more food chain participants (growers, restaurants, farmers markets, wholesalers, distributors, pantries, etc.) with the Florida Department of Agriculture and Consumer Services promotional campaign's "Fresh from Florida" branding services could help businesses and non-profits capitalize on an established state-wide logo and marketing effort in advertising their products to consumers. Much can be accomplished for the regional food system by drawing on the strengths of local food industry leaders and innovators; connecting them with one another, with local policy-makers, and with food system innovators in other regions; and addressing needs for training, marketing, and other resources.

Given the demand for additional local product, new producers are another vital component for the region's food system. The idea of a farm incubator or a network of small incubators, which would provide training and technical assistance for beginning farmers, was greeted with considerable interest by small farmers, market managers, and others. Participants saw existing community gardens as forms of pilot incubators, capable of sharing information on costs, by-laws, infrastructure needs, etc. to guide start-up. Potential partners identified by stakeholders include the Boys and Girls Club, Farm Bureau's Beginning Farmer and Rancher Program, South Fork High School, UF/IFAS Extension, and local farmers. Before an incubator could be established, a lead agency, organization, or business would need to commit to the project; a group of motivated and dedicated participants would need to be identified; and start-up resources (land, funding, etc.) would need to be secured. Lessons learned and materials developed could then be shared with other stakeholders interested in developing new incubators.

The local food system benefits the Martin County region through provision of fresh produce and protein sources, employment opportunities, and value added economic contributions. With strong demand for local food and a diverse network of growers, food entrepreneurs, food pantries, and markets, the region has an opportunity to more strongly connect with and support existing food system participants. Strengthening the existing food system network can build a path for new producers to enter the marketplace more readily, contributing further to the local economy, improving food security, and expanding access to local foods.

\section{Note}

${ }^{1}$ Value Added Contribution is a broad measure of income, representing the sum of employee compensation, proprietor income, other property income, indirect business taxes and capital consumption (depreciation). Value added is a commonly used measure of the contribution of an industry to a regional economy because it avoids double counting of intermediate sales (Court, Hodges and Rahmani 2018).

\section{References}

Court, C. D., A. W. Hodges, and M. Rahmani. 2018.

"Economic Contributions of Agriculture, Natural Resources and Food Industries in Florida in 2016. Economic Impact Analysis Program, Food and Resource Economics Department, University of Florida, Gainesville, FL. https://fred. ifas.ufl.edu/DEStudio/html/EconomicImpactAnalysis/ FloridaAg-FoodIndustryContributions2016WithAppendices.pdf

FDACS. 2016. "2014 Florida Agriculture by the Numbers. Florida Department of Agriculture and Consumer Services, Tallahassee, FL." https://freshfromflorida.s3.amazonaws. com/Media\%2FFiles\%2FMarketing-Development-

Files\%2FFlorida_Agriculture_by_the_Numbers_2014_Statistical_Report.pdf

Martin County Business Development Board. Undated. Martin County Business, Agricultural Edition. Footprint of Agriculture in Martin County. Yesmartinfl.com. https:// www.yesmartinfl.com/images/easyblog_images/63/WBUEdition-21.pdf 
Martin County Property Appraiser. 2019. “Classified Agriculture Standard Report.” Martin County Property Appraiser, Hobe Sound, FL. https://www.pa.martin.fl.us/ tools-downloads/data-downloads

United States Department of Agriculture, Agricultural Marketing Service (USDA-AMS). 2010. "Getting to Scale with Regional Food Hubs." United States Department of Agriculture, Agricultural Marketing Service, Washington, D.C. https://www.usda.gov/media/blog/2010/12/14/ getting-scale-regional-food-hubs

United States Department of Agriculture, National Agricultural Statistics Service (USDA-NASS). 2019. 2017 Census of Agriculture Volume 1. Chapter 2: County Level Data. United States Department of Agriculture, National Agricultural Statistics Service, Washington, D.C. https://www.nass. usda.gov/Publications/AgCensus/2017/Full_Report/ Volume_1,_Chapter_2_County_Level/Florida/ 